\title{
JERZY STEMPOWSKI O SOLI ZIEMI JÓZEFA WITTLINA
}

W 1954 roku w Nowym Jorku ukazało się piąte wydanie Soli ziemi Józefa Wittlina. Autor przesłał jeden z egzemplarzy nowego wydania swojej książki Jerzemu Stempowskiemu, który niezwłocznie powiadomił listownie nadawcę o otrzymanej przesyłce: „Najserdeczniej dziękuję za Sól ziemi z piękną dedykacją. Zacząłem ją czytać i jestem nią zachwycony. Czytałem ją oczywiście zaraz po jej ukazaniu się w kraju i potem jeszcze raz po francusku. [...] Sól ziemi wytrzymała zwycięsko największą próbę, próbę czasu, i czytam ją za każdym razem inaczej wprawdzie, ale z równą przyjemnością"’.

W 1955 roku Jerzy Stempowski opublikował na łamach „Kultury” krótką recenzję poświęconą pierwszej części trylogii o Cierpliwym Piechurze.

Przyczyn wciąż niesłabnącego zainteresowania książką, która nie utraciła od czasu swojej premiery wydawniczej w 1936 roku „uroku nowości”, eseista dopatrywał się w sposobie kreowania przez jej autora świata przedstawionego. „Sama koncepcja artystyczna Soli ziemi wydaje mi się dziś najbardziej uderzającym aspektem tej powieści”2.

Sól ziemi była dla Jerzego Stempowskiego ,jedną z najlepszych powieści polskich dwudziestolecia niepodległości”, a także narracją sytuującą się ponad granicami kulturowymi. Pomimo wciąż zmieniających

1 List Jerzego Stempowskiego do Józefa Wittlina z 8 II 1955, w: J. Stempowski, Listy. Listy do różnych adresatów..., słowo wstępne Jan Kott, Wojciech Karpiński, posłowie Andrzej Stanisław Kowalczyk, wybór i red. Barbara Torunczyk, Warszawa 2000, s. 174.

2 Paweł Hostowiec, Nowe wydanie «Soli ziemi», „Kultura” 1955, nr 7/8, s. 200. 
się tendencji literackich i upodobań czytelniczych zachowała charakter uniwersalny. Nie utraciła również rysu indywidualnego. Wittlin pozostał twórcą wolnym, spojrzał na doświadczenie I wojny światowej z pewnego oddalenia, tym samym jego powieść zbliżyła się miarą do dzieł twórców antycznych, którzy dbali o zachowanie proporcji między rzeczą a słowem, które miało o niej mówić. Być może dlatego, jak mniemał autor recenzji, opowieść o losach Piotra Niewiadomskiego, analfabety, syna nieznanego ojca i Hucułki, uczestnika wielkiej wojny zyskała uznanie czytelników i znawców literatury z różnych krajów.

Tekst $O$ «Soli Ziemi» Wittlina jest zapisem wrażenia z pierwszej lektury powieści Wittlina, o której Stempowski wspominał we fragmencie przytoczonego listu. W 1936 roku odczytywał Powieść o Cierpliwym Piechurze w kontekście bieżących wydarzeń, a w zasadzie wartościował ją na tle ówczesnej kondycji moralnej Europy, zagrożonej ekspansją dwóch totalitaryzmów, stojącej u progu II wojny światowej. Mamy przed sobą tekst, który nie jest jedynie laudacją, wyrazem skupienia recenzenta na walorach kompozycyjnych danego dzieła. Stempowski rozważa powieść Wittlina w odniesieniu do dorobku intelektualnego pisarzy i myślicieli, którzy na przestrzeni wieków propagowali idee humanitaryzmu i którzy stawiali opór ideologicznym machinacjom. 


\section{[JERZY STEMPOWSKI]}

\section{O SOLI ZIEMI WITTLINA}

Od kilku lat przeżywamy w Warszawie okres wielkiego zainteresowania krytyką formalną. Wśród moich łaskawych słuchaczy znajduje się na pewno sporo osób, które mogłyby ze znawstwem rozważyć zagadnienia budowy postaci w powieści Wittlina, naturę jego metafor i sposoby oddawania płynięcia czasu. Zagadnienia te są warte rozważania i - wobec zainteresowania, jakie budzą w młodszym pokoleniu krytyków i badaczy literatury - będą zapewne rozważone. Zanim jednak następne tomy Powieści o Cierpliwym Piechurze 3 dostarczą nam materiału do przyjrzenia się budowie tego wielkiego fresku, chciałbym zacząć od kilku spostrzeżeń ogólnych. Kładąc na warsztat pierwszą dużą powieść autora znanego już dobrze z różnych innych rodzajów twórczości literackiej, wypada być może spojrzeć nasamprzód na całość jego utworu, na jego ogólną postawę moralną i artystyczną, postarać się określić jego miejsce w rodzaju powieściowym.

\section{\&}

Sól Ziemi jest powieścią o wojnie, operującą olbrzymim, bardzo przemyślanym materiałem obserwacyjnym. Niby na gigantycznym fresku autor rozwija przed nami ułożone w organiczną całość tysiące malowniczych szczegółów, tradycji, gestów, odruchów, manier, sposobów bycia, interesów, regulaminów i wiązań organizacyjnych, z których składa się Stara Austria.

O Starej Austrii, dwugłowej monarchii, będącej legendarną wieżą Babel czasów nowożytnych, dawno już nie było mowy. Segregacja

Tytuł trylogii Józefa Wittlina, której pierwszą część stanowiła Sól ziemi. Kolejne części Powieści o Cierpliwym Piechurze - mające nosić tytuły: Zdrowa śmierć, Dziura w niebie - nie powstały. Wszystkie przypisy do niniejszego tekstu pochodzą od edytora-M. Ch. 
pomieszanych w niej języków nastąpiła zaledwie przed siedemnastu laty, a już obraz tego dziwnego tworu zdaje się zacierać w naszej pamięci. Nawet starzy radcy austriaccy, urzędujący sobie w naszych ministerstwach zdają się przypominać sobie tylko fragmenty i strzępy niedawnej przeszłości. Dawna apostolska ${ }^{4}$ monarchia pocięta została nożem granic i kraje jej zrosły się w nowym porządku. Tysiące zazębień stworzonych przez tradycje, interesy, sposoby bycia, sympatie, idiosynkrazje, porozumienia i przepisy prawne, łączące między sobą części składowe Starej Austrii i jej poddanych, zostały rozerwane. Wzdłuż nowych słupów granicznych strażnicy wydeptali po obu stronach równoległe ścieżki, między którymi pas graniczny porósł głęboką trawą, przebieganą z rzadka przez stopy przemytników. Stare, odwieczne drogi, którymi jeżdżono na jarmarki i na imieniny, są zamknięte rogatkami lub zasiekami z drutu i roślinność zdążyła już pokryć ich jezdnię. Nikomu nie przychodzi dziś na myśl, że wszystkie te wiekowe więzy, łączące między sobą b[yłych] poddanych apostolskich cesarzów, mogłyby w ten lub inny sposób ożyć. Narody Europy zamknęły się w swych granicach, zasłoniły okna żelaznymi żaluzjami i wzajemne pogróżki stały się ich formą powitania. Nikt zdaje się dziś nie pamiętać o aspekcie wiekuistym Starej Austrii, o reprezentowanej przez nią - po wieży Babel, po państwie Aleksandra Macedońskiego i po Imperium Rzymskim - idei ludów osiadłych na swych śmieciach i zachowujących swe tradycje i odrazy, a jednak związanych wspólną organizacją polityczną. Ktokolwiek podjąłby kiedyś na nowo ideę Stanów Zjednoczonych Europy5 ${ }^{5}$ będzie musiał wziąć do ręki starą c.k. konsty-

\footnotetext{
4 Cesarz Austrii nosił też tytuł Apostolskiego Króla Węgier.

5 Po I wojnie światowej w kręgach europejskiej elity umysłowej zrodziła się idea utworzenia Stanów Zjednoczonych Europy. Wśród propagatorów stworzenia wspólnoty europejskiej znalazł się Richard Coudenhove-Kalergi. Na łamach wydawanego przez siebie czasopisma „Paneuropa" postulował utworzenie jednego państwa europejskiego. Jego koncepcja zainspirowała m.in. Aristide'a Brianda (1862-1932), francuskiego polityka, wielokrotnego premiera Francji i ministra w latach 1909-1929, który w 1930 podczas obrad Ligi Narodów zaproponował utworzenie Unii Federacyjnej. Miały do niej należeć trzy państwa założycielskie: Francja, Wielka Brytania, Niemcy oraz pozostałe państwa europejskie z pominięciem Rosji i Turcji. W 1930 Édouard Herriot (1872-1957), francuski polityk, trzykrotny premier Francji w latach 1924-1925, 1926 i 1932, napisał książkę Stany Zjednoczone Europy (wyd. 1930), która stała się ważnym gło-
} 
tucję, podręcznik austriackiego prawa państwowego Ludwika Gumplowicza $^{6}$, aby zobaczyć, w jakie formuły ubiera się prastara Chimera.

Wywołanie z niepamięci spraw i obrazów o wielkim zasięgu, łączących się z odwiecznymi instynktami ludzkości, zawsze było dziełem artystów. Stara Austria, którą ukazuje Wittlin w Soli Ziemi, nie jest już więcej młodą Chimerą, kuszącą Sfinksa, ale Chimerą sklerotyczną, agonizującą, popchniętą na obcą jej geniuszowi drogę czynów wojennych, mającą właśnie pogrążyć swe ludy w otchłani niedoli, zbliżającą się nieuchronnie do katastrofy. Niemniej jej osobliwa i paradoksalna uroda jest wciąż jeszcze przytomna na stronicach książki Wittlina, podobna do zanotowanych przezeń ,austriackich fizjonomii, które tak szczęśliwe skupiają cechy romańskiej, germańskiej i słowiańskiej rasy"7.

Ta olbrzymia masa materiału obserwacyjnego, gotowa - jak niegdyś w rzeczywistości austriackiej - zatopić każdą myśl porządkującą, pod piórem Wittlina organizuje się w pewną całość, układa się niepostrzeżenie w pewną hierarchię wartości. Proces przetwarzania materiału obserwacyjnego w dzieło sztuki, podjęty przez Wittlina na ogromną skalę w Soli Ziemi, wydaje mi się najbardziej frapującą i aktualną stroną jego powieści.

Świat artysty jest zasadniczo różny od świata znanego nam z doświadczenia i obserwacji. Ten ostatni nie jest ani dobry, ani zły, nie posiada żadnego własnego porządku w odniesieniu do wartości. Świat artysty natomiast jest nasycony uczuciowo, uporządkowany według wartości. Sztuka, mówił Rafael, jest gloryfikacją natury - una glorificazione della natura. Zdolność do ujmowania świata doświadczalnego w pewien porządek wartości, w pewne skróty i uproszczenia, dokony-

sem w dyskusji o potrzebie stworzenia federacji państw europejskich. Powrócono do niej dopiero po zakończeniu II wojny światowej. Winston Churchill 19 września 1946, w mowie wygłoszonej na uniwersytecie $w$ Zurychu, powrócił do koncepcji stworzenia federacji państw europejskich na wzór Stanów Zjednoczonych.

6 Ludwik Gumplowicz (1838-1909), socjolog, teoretyk prawa; od 1882 r. był profesorem na Uniwersytecie w Grazu. W 1892 został profesorem zwyczajnym prawa państwowego. Stawiał śmiałe hipotezy socjologiczne, uznawany jest za przedstawiciela teorii konfliktu. Uważał, że socjologia powinna badać historię jako proces przyrodniczy.

Jozef Wittlin, Sól ziemi, Warszawa 1936, s. 22. 
wania w nim szczęśliwego wyboru, gloryfikowania go, jak mówił Rafael, towarzyszy człowiekowi od jego zarania. Już nasi przodkowie odlegli w swych pieczarach, posiadali to uzdolnienie, wytwarzali dookoła siebie fikcyjny świat sztuki, otaczający ich atmosferą nasyconą uczuciowo. Człowiek stwarza dookoła siebie warunki, umożliwiające jego egzystencję w mrocznym klimacie północy. W tym samym sensie artysta tworzy pewną aurę moralną, broniącą naszego życia uczuciowego od brutalnego zetknięcia z niegościnnym klimatem moralnym.

Ta rola świata sztuki uderza nas szczególnie, kiedy mamy przed sobą powieść opisującą wojnę. Wojna wytwarza szczególnie niegościnny klimat moralny o straszliwym ciśnieniu, łamiącym delikatne wiązania naszego życia uczuciowego. Aby ostać się jej niszczycielskiemu pochodowi, walczący zmuszeni są do przyjęcia pewnej określonej hierarchii wartości, moralności oblężonego miasta, w którym nie ma więcej żadnych spraw i ocen indywidualnych i wszystko podporządkowane jest doraźnym koniecznościom wojennym, reprezentowanym chociażby przez regulamin piechoty, interpretowany przez znanego czytelnikom Wittlina sztabsfeldfebla Bachmatiuka ${ }^{8}$.

Pod ciśnieniem moralnym wielkiej wojny załamała się prawie cała elita umysłowa Europy. Koła najbardziej powołane do bronienia spadku po Erazmie z Rotterdamu, autorze Antipolem $[u] s a^{9}$, po Wolterze, po Kancie, autorze rozprawy Zum ewigen Frieden ${ }^{10}$, z której narodził się w sto lat później pakt Ligi Narodów ${ }^{11}$, koła te zawiodły. Wszyscy

\footnotetext{
8 Rudolf Bachmatiuk, jeden z bohaterów Soli ziemi Józefa Wittlina. Ukrainiec, syn wójta gminy nad Seretem, sierżant sztabowy, przygotowujący rekrutów do wcielenia do armii, entuzjasta służby wojskowej, fanatycznie wypełniający swoje obowiązki, bezgranicznie oddany idei regulaminu i dyscypliny.

9 Antipolemus, albo apel do rozumu, religii, humanizmu przeciwko wojnie, 1517, (łac.).

10 O wiecznym pokoju (niem.). Traktat Kanta ukazał się w 1795, termin „wieczny pokój” autor bezpośrednio zaczerpnął z rozprawy abbe Castela Traite de la paix perpetuelle, 1713. Niemiecki filozof porusza w nim tematykę dotyczącą delegalizacji wojny i tęsknoty za powszechnym i wiecznym pokojem. Dzieło stanowi podsumowanie intelektualnych zmagań wybitnych myślicieli, którzy na przestrzeni wieków zastanawiali się nad możliwością podjęcia działań, które pozwoliłyby na pokojowe współżycie państw i narodów.

11 Pakt Ligi Narodów zaczął obowiązywać od 20 stycznia 1920, stanowił część Traktatu Wersalskiego podpisanego 28 czerwca 1919, który formalnie zakończył I wojnę światową.
} 
pamiętają manifest 93 uczonych i pisarzy niemieckich ${ }^{12}$ [i] Hassgesänge Lissauera ${ }^{13}$ :

Wir lieben vereint, wir hassen vereint, Wir haben alle nur einen Feind - England ${ }^{14}$.

Po drugiej stronie frontu w tymże czasie Henri Bergson ${ }^{15}$ pisał dla podniesienia ducha wojennego broszurki wydawane staraniem drugiego biura Sztabu francuskiego. Joseph Bédier ${ }^{16}$ na podstawie listów i notatek znajdowanych na trupach niemieckich usiłował dowieść, że Niemcy są barbarzyńcami. Paul Géraldy ${ }^{17}$ przedstawił wojnę na użytek dam w książeczce pod tytułem La guerre, Madame... ${ }^{18}$. Sam Anatol W preambule paktu zostały zawarte główne idee Ligi Narodów, mówiące o potrzebie wzmacnia-
nia współpracy międzynarodowej w celu utrzymania pokoju na świecie.
12 Manifestem Dziewięćdziesięciu Trzech Intelektualistów Niemieckich nazwano deklara-
cję udzielenia w 1914 r. poparcia dla działań wojsk niemieckich podczas I wojny światowej
na terenach neutralnej Belgii. Działania te zostały powszechnie określone „gwałtem na Belgii”.
Dokument został podpisany przez liczną grupę niemieckich naukowców, artystów, psychiatrów,
chemików. W 1921 został opublikowany przez „The New York Times” wraz z listą nazwisk
wszystkich sygnatariuszy manifestu.
13 Właśc. Hassgesang gegen England [Hymn nienawiści do Anglii], został napisany w 1914
przez Ernesta Lissauera (1882-1937), niemieckiego poetę pochodzenia żydowskiego. Utwór
cieszył się dużym uznaniem. Autor hymnu został za niego uhonorowany Orderem Czerwonego
Orła. Publikowany był we wszelkich gazetach, żołnierze armii niemieckiej znali go na pamięć,
skomponowano do niego muzykę, śpiewano go wówczas w teatrach. Po zakończeniu I wojny
światowej Niemcy starały się nawiązać pozytywne stosunki z Anglią, w rezultacie zabroniono
publikowania jakichkolwiek utworów Lissauera.

14 „Kochamy razem, razem nienawidzimy, / Wszyscy mamy tylko jednego wroga - Anglię” (tłum. z niem. Jan Zieliński).

15 Henri Bergson (1859-1941), francuski filozof, pisarz, twórca koncepcji élan vital; w 1927 otrzymał Nagrodę Nobla w dziedzinie literatury; autor m.in. Ewolucji niemieckiego imperiali$z m u$.

16 Joseph Bédier (1864-1938) francuski krytyk literacki i pisarz, wybitny mediewista, autor m.in. Historii literatury francuskiej, 1923-1924; Jerzy Stempowski nawiązuje do książki Les crimes allemands d'après les témoignages allemands, 1915. Bédier uporządkował znalezione przez siebie fragmenty dzienników, notatek i listów żołnierzy niemieckich i na podstawie zestawionych ze sobą relacji z frontu, wskazał na trzydzieści sześć przypadków sadystycznych i seksualnych wykroczeń, dokonanych na żołnierzach francuskich i cywilach z Belgii.

17 Paul Géraldy, pseud. Paul Lefèvre (1885-1983), francuski poeta, pisarz i dramaturg.

18 Wojna, proszę Pani... (fr.), 1919. Jerzy Stempowski w szkicu literackim Żolnierz niemiecki jako moralista, 1930, tak wzmiankuje o tej powieści: „Géraldy, autor znanego tomiku wierszy Toi 
France ${ }^{19} \mathrm{w}$ liście otwartym do ówczesnego ministra wojny, generała Messimy $^{20}$, prosił go o przyjęcie, pomimo podeszłego wieku, do służby wojskowej. Uczeni naturaliści i technicy obu obozów, prezesi akademii i kierownicy wielkich fundacji naukowych, pracowali nad fabrykacją gazów wojennych.

Zachowanie się elity umysłowej Europy wywierało katastrofalne wrażenie w okopach. Moi koledzy uniwersyteccy, walczący na froncie francuskim, przyjeżdżali na urlopy coraz bardziej przerażeni i zniechęceni. Myśleliśmy, mówili, że za nami stoi wielka cywilizacja, której wypadło nam bronić w okopach. Zachowanie się naszej elity dowodzi, że było to tylko złudzenie, że żadnej cywilizacji za nami nie ma, i że ofiary nasze są bezużyteczne.

Wśród tego posępnego obrazu głos starego lekarza i przyjaciela człowieka Sigmunda Freuda zabrzmiał samotny, złowróżebny, straszliwy, jak gdyby miał być miarą upadku moralnego Europy. W swym eseju pt. Zeitgemässes über den Tod und Krieg ${ }^{21}$, ogłoszonym podczas wojny i konfiskowanym przez wszystkie cenzury, stary uczony wypowiedział mniemanie, że moralność wojujących Europejczyków cofnęła się poniżej poziomu moralnego ludów pierwotnych, u których na ogół zwycięzcy wojownicy, o ile zmuszeni byli zabijać, zobowiązani są do odbywania pokuty. Ale o pokucie nie było mowy w Europie. Jej elita umysłowa $\mathrm{z}$ najsławniejszymi filozofami na czele, przyjąwszy

et moi, napisał podczas wojny bardzo elegancką, sprytną i głupiutką książeczkę La guerre, madame..., mającą za zadanie pokrzepienie dam strapionych przez wojnę. Głównym wysuwanym przezeń argumentem jest, że panie pozostające w domu nie powinny rozpaczać, ponieważ ich mężowie i synowie czują się doskonale w okopach i odnoszą się z największą pogodą do swych nowych warunków życia”, zob. J. Stempowski, Szkice literackie, t. 1: Chimera jako zwierzę pociagowe 1926-1941, wybór i oprac. Jerzy Timoszewicz, Warszawa 2001, s. 32.

19 Anatol France, właśc. François-Anatole Thibault (1844-1924), francuski powieściopisarz i krytyk literacki, członek Akademii Francuskiej od 1896, laureat Nagrody Nobla w 1921, współpracował z czasopismami komunistycznymi „L'Humanité” i „Clarté”.

20 Adolphe Messimy (1869-1939), żołnierz i polityk francuski, minister wojny w rządzie René Vivianiego od 13 czerwca do 26 sierpnia 1914.

${ }^{21}$ Aktualne uwagi o wojnie i o śmierci (niem.), esej został opublikowany w 1915. Freud odwołuje się w nim do popędu śmierci jako komponentu ludzkiej natury, który doprowadza do unicestwienia wszelkich wytworów kultury. 
jednolitą moralność obozu warownego - wir lieben vereint, wir hassen vereint - pośpieszyła udzielić absolutorium wszystkim walczącym. Pewien zapalczywy pastor w znakomitym kazaniu Jezus aus $M G$, usiłował nawet wskazać, że Jezus gdyby żył dziś, byłby żołnierzem w niemieckiej kompanii K.[arabinów] M.[aszynowych].

W tym zachowaniu się elity europejskiej było coś nowego, czego nie widziały wieki poprzednie. Aby zdać sobie sprawę z nowości sytuacji, wystarczy przypomnieć sobie podobne pod wieloma względami do naszych czasy Napoleona. Literatura piękna Cesarstwa, w swych najwybitniejszych przedstawicielach, którzy weszli do historii literatury, oprała się straszliwej demagogii Napoleona, nie ulegała wytworzonemu przezeń ciśnieniu i zachowała niezależność moralną. Wielkie inteligencje i talenty rzadko tylko towarzyszy z wielkimi charakterami. Toteż ani Chateaubriand ${ }^{22}$, ani Paul-Luis Courier ${ }^{23}$, ani Benjamin Con$\operatorname{stant}^{24}$, ani Madame de Sta[ë] $1^{25}$ nie byli podobni do niezłomnych Katonów, wszyscy mieli chwile słabości i starali się prześliznąć między wypadkami. Wszyscy jednak z uporem stawiali czoła próbom mobilizacji literatury przez Napoleona. Walka z nim była niełatwa. Napoleon był człowiekiem całkowicie bezwzględnym, pozbawionymi skrupułów, o żelaznej woli, i do zdobycia i podporządkowania sobie literatury przywiązywał największą wagę. W niedawno ogłoszonej książce John Charpentier ${ }^{26}$ opowiedział fascynującą i pouczającą dla nas historię tej

22 François-René de Chateaubriand (1768-1848), jeden z pisarzy francuskiego preromantyzmu, inicjator francuskiego romantyzmu, autor m.in. Essai sur les révolutions, 1797.

23 Paul-Louis Courier (1773-1825), francuski pisarz, hellenista, autor pism o tematyce społecznej i politycznej, które ukazały się w zbiorze Le Censeur Européen, 1818.

24 Henri-Benjamin Constant de Rebecque (1767-1830), francuski pisarz, filozof, działacz polityczny, w czasie Restauracji stanął na czele partii liberalnej, autor pism politycznych, twórca powieści Adolf, 1816.

25 Madame de Staël (1776-1817), właśc. Anne Louise Necker baronowa de Staël-Holstein; francuska powieściopisarka i publicystka pochodząca ze Szwajcarii, teoretyk preromantyzmu i romantyzmu, autorka dzieła De la litérature considérée dans ses rapports avec les institutions sociales, 1800.

26 John Charpentier (1880-1949) intelektualista, historyk, bibliotekarz, autor biografii pisarzy i filozofów, pisał przede wszystkim po francusku. Stempowski nawiązuje do książki $\mathrm{Na}$ poléon te les hommes de lettres de son temps, 1935. 
walki, zakończonej klęską Napoleona. Żywioł umysłowy i artystyczny, w którym płynęła ówczesna elita Europy, okazał się oporny na wszelkie próby mobilizacji.

Załamanie się inteligencji europejskiej podczas wojny wytworzyło w obliczu moralnym Europy olbrzymie szczerby, których wypełnienie zdaje się wymagać dłuższego czasu i większego wysiłku niż odbudowywanie zniszczonych przez wojnę prowincji ${ }^{27}$. Według świadectwa Platona, Sokrates mniemał, że cnota jest związana z wiedzą o moralności, że jest wiedzą o sprawach moralnych. Myśl Sokratesa znajdujemy potem w tej lub innej postaci we wszystkich niemal książkach traktujących o etyce. Od czasów greckich, przez wszystkie książki szkolne przewija się myśl, że pewna wiedza specyficzna jest identyczna z moralnością, a wiedza i inteligencja w ogóle są niezbędnym czynnikiem po[s]tępu moralnego. Przed dwoma i pół tysiącami lat Sokrates znajdował się na początku długiego szereg[u] filozofów. Jeżeli więc chodzi o wiedzę specjalną o moralności, została ona pogłębiona przez wysiłki kilkudziesięciu pokoleń uczonych i myślicieli. A jednak miejsce uczonych moralistów w naszej hierarchii społecznej i doniosłość praktyczna ich nauk jest dziś mniejsza bodaj niż w Atenach. Jeżeli dziś nie poją filozofów cykutą, lecz co najwyżej olejkiem rycynowym, to taka łagodność naszego obyczaju pochodzi stąd, że uczeni naszych czasów ni[e] wchodzą jak Sokrates w konflikty z ustalonymi systemami moralności praktycznej, że są wszyscy prawie, według terminologii naszych czasów, gleichgeschaltet ${ }^{28}$.

Jeszcze dziwniejsza refleksja budzi stosunek ogólnej wiedzy i inteligencji do moralności. Dzięki obecnemu systemowi szkolnemu, nigdy zapewne tak wielkie ilości młodzieży nie zasiadały na ławach szkół

27 W maszynopisie $O$ «Soli ziemi» Wittlina znajduje się w tym miejscu fragment tekstu, skreślony przez autora: „Dwa i pół tysiąca lat temu Sokrates wypowiedział myśl, że moralność jest pewnego rodzaju wiedzą. Od tego czasu wszystkie książki szkolne traktujące o etyce mówią, że moralność jest wiedzą o sprawach moralnych, i że rozszerzenie wiedzy i inteligencji są niezbędnym warunkiem postępu moralnego. Od czasów Sokratesa przybyły nam setki książek mówiących o etyce. Kilkadziesiąt pokoleń filozofów i myślicieli pogłębiło wiedzę specjalną [...]”.

28 Zglajszachtowani (niem.). 
i nie były zmuszone do metodycznej nauki. Miliony żyjących obecnie osób przesiedziały kilkanaście lat w murach szkolnych, zdobywając wiedzę książkową i laboratoryjną. Fizjolodzy przypuszczają, że sama nawet budowa ciała ludzi współczesnych uległa głębokim zmianom na skutek zwiększenia się ilości przedmiotów i przedłużenia lat nauki. Tymczasem większość wybryków i gwałtów, obrażających dziś nasze uczucia moralne, wychodzi nie z ciemnego motłochu miejskiego lub spośród chłopów orzących ziemię, ale właśnie z murów wyższych uczelni i ze środowisk najgęściej zdobionych dyplomami uniwersyteckimi. W wielu krajach lud zaczął odpychać dziś od siebie słowo drukowane jako nosiciela zgnilizny moralnej.

Nauka szkolna zdaje się obecnie uprzystępniać umysły dla sofistyki moralnej i korupcji. Chcąc wyprowadzić dzisiejszy typ moralny człowieka wykształconego z wzorów klasycznych, rozpoznalibyśmy w nim spadkobiercę głównego antagonisty Sokratesa z dialogów Platona, mianowicie Kalliklesa, dowodzącego, że przepisy prawa i moralności przed dwoma i pół tysiącami lat trwa nadal i nasze czasy przyniosły w niej wielką klęskę Sokratesa, zwyciężonego tym razem nie przez truciznę, ale przez dezercję domniemanych uczniów.

Ten stan moralny dzisiejszej Europy ma więcej niż jedną przyczynę. Jego skrystalizowanie nastąpiło jednak pod wpływem wojny. Te[n] niepotrzebny już nikomu grymas na obliczu moralnym Europy trwa nadal, i dlatego każdy rok przynosi nam nowe powieści o wojnie. Wszyscy marznący i więdnący w niegościnnym klimacie moralnym dzisiejszej Europy powracają myślą do źródła jego zepsucia, do peccatum originale $^{29}$ dzisiejszej inteligencji, do fatalnego rozwidlenia się dróg, na którym życie umysłowe świata utraciło swoją niepodległość.

Przed jedenastu laty wyszła z druku pierwsza książka Wittlina Wojna, pokój $i$ dusza poety ${ }^{30}$. Na okładce jej znajdujemy już zapowiedź Powieści o Cierpliwym Piechurze. Przez jedenaście lat zatem Wittlin

\footnotetext{
29 Grzech pierworodny (łac.).

30 Pierwsze wydanie: Józef Wittlin, Wojna, pokój i dusza poety. Szkice literackie i przemówienia, Zamość 1925.
} 
zmagał się w sobie z wizją wojny, starając się rozluźnić jej straszliwy ucisk moralny. W swym pierwszym eseju Wittlin jest pełen niewymownej goryczy i wzburzenia. Essay jego pisany był jeszcze przed powieścią Remarque'a ${ }^{31}$, w czasach, kiedy wojna była świeżym wspomnieniem. Widzimy w nim Wittlina jeszcze wzburzonego, protestującego, pełnego żalu i skargi, jeszcze nie wolnego od przymusu. Nonkonformiści, typu Wittlina lub Remarque'a, przeżywają te sprawy nierównie trudniej, boleśniej niż konformiści, spłacający swój domniemany dług ojczyźnie paru pieśniami nienawiści i przechodzący już lekką stopą do następnych czasów. W Soli Ziemi widzimy Wittlina już wolnego wewnętrznie, patrzącego na wojnę już z pewnego dystansu, mającego w stosunku do swojego przedmiotu swobodę sądu i wyboru. Porównując między sobą różne powieści z wielkiej wojny, spostrzeżemy, że, ostatnia z kolei, Sól Ziemi, posiada największą swobodę i nieprzymuszoność wewnętrzną. Już dlatego powieść ta jest dla nas dobrą nowiną, zapowiadając możliwość wyzwolenia się spod ciążącego jeszcze na nas wszystkich ucisku moralnego wojny, wyjścia z jej niegościnnego klimatu moralnego.

W swej książce o powieści współczesnej Albert Thibaudet ${ }^{32}$ zauważa, że wszystkie prawie powieści o wojnie należą do kategorii ,powieści przeznaczenia" - roman de la destinée, w której widzimy los bohaterów rozwijający się niezależnie od ich inicjatywy. Sam[ego] nawet Le Feu Barbussa ${ }^{33}$ Thibaudet nie waha się zaliczyć do tej kategorii.

31 Erich Maria Remarque, właśc. Erich Mark Remerk (1898-1970), pisarz niemiecki. Uczestniczył w I wojnie światowej. Na podstawie swoich doświadczeń z frontu napisał powieść Na zachodzie bez zmian, 1929 (I wyd. polskie: Warszawa 1930). Jerzy Stempowski poświęcił tej powieści szkic krytycznoliteracki: Żotnierz niemiecki jako moralista, 1930, zob. J. Stempowski, Szkice literackie, t. 1, dz. cyt., s. 29-40.

32 Albert Thibaudet (1874-1936), francuski krytyk literacki i eseista, uczeń Bergsona, otrzymał katedrę literatury francuskiej w Genewie, w latach 1911-1936 prowadził kronikę literacką w „Nouvelle Revue Française”, sympatyzował z pisarzami prawicowymi. Jerzy Stempowski odwołuje się do: Histoire de la littérature française de 1789 à nos jours, 1936. Poświęcił jego książce Physiologie de la critique (1930) szkic literacki Fizjologia krytyki. Pierwodruk w „Wiadomościach Literackich" 1931, nr 8.

33 Henri Barbusse (1873-1935), francuski pisarz, dziennikarz, w 1916 ukazała się jego powieść Ogień (I wyd. polskie: H. Barbusse, Ogień: pamiętnik w okopach, Lwów 1919) oparta na 
Nasz tragiczny czas, sądzi, powinien był przebudzić w nas zmysł przeznaczenia, jaki mieli starożytni Grecy. Ale już Thibaudet spostrzega pewną sprzeczność między zmysłem przeznaczenia i zaletami żołnierza-zwycięzcy. „Najwyższą wartość na wojnie posiadają: zmysł przygody, wola, pomysłowość, gorące skupienie na chwili obecnej, te wszystkie zalety, które Zachód skupił w swym pierwszym bohaterze, boskim Ulissesie. Nie możemy sobie natomiast wyobrazić żadnego Ulissesa Wschodu".

Sól Ziemi odpowiada całkowicie klasyfikacji Thibaudeta. Jak w powieściach wschodnich Piotr Niewiadomski idzie za swym losem jak kropla wody niesiona przez potok. To poddanie się przeznaczeniu wydaje się mieścić u Wittlina głębsze znaczenie. Autor zna tyle różnych odcieni tej bierności, tyle razy wraca do niej, zna jej tyle sekretów, że chcielibyśmy się nad nią bliżej zastanowić.

Wschodni fatalizm zdaje się być pewną granicą naturalną wszelkiego przymusu. Wschód kształtował się pod władzą despotów, nie znających żadnych granic swej fantazji. Sen tyrana jest równy modlitwie, mówi wschodnie przysłowie. Wittlin przenosi postawę moralną na teren wojny współczesnej. Przymus moralny ${ }^{34}$ niesiony przez wojnę wywołuje postawy bierne, będące jednocześnie nieprzydatne dla wojny, odbierający przymuszonym zdolność zwyciężania, prowadzące wojnę do absurdu. Jako powieść przeznaczenia Sól Ziemi zdaje się więc nakreślać wojnie pewną nową granicę władzy.

\section{\&}

W zakończeniu chciałbym powiedzieć jeszcze kilka słów o roli społecznej powieści typu Soli Ziemi, powieści rozluźniającej ciśnienie wielkich przymusów moralnych.

\footnotetext{
doświadczeniach pisarza z okresu I wojny światowej. Zawarł w niej głęboką antypatię do militaryzmu, utwór otrzymał Nagrodę Goncourtów w 1916 r.

34 W maszynopisie $O$ «Soli ziemi» Wittlina znajduje się skreślone przez autora słowo: „muzułmańskie".
} 
Zmarły przed paru laty Jacques Bainville ${ }^{35}$ w swej książce o Napoleonie mówi, że cesarz nie obawiał się nikogo tak, jak graczy na zniżkę, les joueurs a la baisse ${ }^{36}$, ludzi nie poddających się jego demagogii i zachowujących podczas największych zwycięstw i triumfów trzeźwą niezależność sądu. Sam Napoleon był pierwszym wodzem, korzystającym z powszechnego poboru rekruta i mobilizując wszystkie siły narodu, stworzył olbrzymie ciśnienie moralne, nad którym czuwał nieustannie osobiście. Ale pod jego panowaniem we Francji pojawili się młodzi ele[g]anci w kosmatych cylindrach, z sękatymi kijami i impertynenckimi lornetkami w ręku, nie poddający się urokowi wielkiego cesarza i jego demagogii. Na wszystkie grzmiące frazesy jak: „czterdzieści wieków patrzy na was” lub „kto powie - byłem pod Austerlitz - wszyscy mu odpowiedzą - voila un brave ${ }^{37}$ - odpowiadali chłodno - c est incroyable ${ }^{38 "}$ ". Na incroyablach i ich towarzyszkach, które nazywano les merveilleuses ${ }^{39}$, kończył się urok wielkiego panowania. Jedno zimne słowo rozładowywało kolosalne napięcia. Bez uroku wielkości cesarstwo obracało się w farsę i nicość. Tu tkwi źródło wiary Napoleona w siłę słowa, siłę magiczną, mogącą w niewiadomy bliżej sposób obalić największe potęgi. Napoleon przeciwstawiał tej magicznej sile słowa potęgę swojej cenzury. Cenzura zdaje się być odtąd miarą, przy pomocy której możemy ocenić odradzanie się wiary w magiczną siłę słowa. Społeczeństwa żyjące bez cenzury nie wierzą w taką potęgę. Ale wszędzie tam, gdzie odżywa na nowo odwieczna i chimeryczna myśl przerobienia ludzi przy pomocy przymusu, tam powstaje obawa przed niebezpiecznym słowem, mogącym obrócić wniwecz największe potęgi.

35 Jacques Bainville (1879-1936) francuski historyk i dziennikarz, obok Charlesa Maurrasa i Léona Daudeta, główna postać Action Française, członek Akademii Francuskiej od 1935 r. Stempowski odwołuje się do książki Napoléon, 1931.

36 Gracze giełdowi (fr.).

37 Oto mężny (fr.).

38 To niesłychane (fr.).

39 Cudowności (fr.). 


\section{Nota edytorska}

Odczyt $O$ «Soli ziemi» Wittlina Jerzego Stempowskiego nie był dotąd publikowany. Nie udało się ustalić dokładnej daty jego powstania. Można jedynie przypuszczać, że został spisany kilka dni po śmierci Jacquesa Bainville'a. Dokumentuje ten fakt Stempowski w odczycie poświęconym powieści Wittlina: „Zmarły przed kilku dniami Jacques Bainville w swej książce o Napoleonie mówi, że cesarz nie obawiał się nikogo tak, jak graczy na zniżkę, les joueurs a la baisse, ludzi nie poddających się jego demagogii i zachowujących podczas największych zwycięstw i triumfów trzeźwą niezależność sądu”. Bainville zmarł dokładnie 9 II 1936 roku. Tego samego dnia na pierwszej stronie „Wiadomości Literackich" (nr 6) ukazał się werdykt jury czasopisma, przyznający wyróżnienie i nagrodę dla autora najwybitniejszej książki roku: „Józef Wittlin podwójnym laureatem nagrody wydawnictwa i nagrody imienia czytelników «Wiadomości Literackich»".

Trudno ustalić miejsce i datę wygłoszenia odczytu. Stempowski w latach 30. występował z odczytami m.in. w Warszawie, Krakowie, Białymstoku, Lwowie, Krzemieńcu, a także w Polskim Radiu. Może wygłosił go przed studentami Państwowego Instytutu Sztuki Teatralnej, gdzie od 1935 roku prowadził wykłady z zakresu historii konwencji artystycznych?

Tekst odczytu $O$ «Soli ziemi» Wittlina, na który zwrócił moją uwagę Jerzy Timoszewicz został opracowany na podstawie maszynopisu, znajdującego się w Dziale Rękopisów Biblioteki Uniwersytetu Warszawskiego, sygn. 1503(44). Obejmuje strony 1-13. Znajdują się w nim nieliczne poprawki dokonane przez autora: skreślenia, dopiski i adnotacje na marginesie. Przeważnie mają charakter redakcyjny. Istotne zmiany $\mathrm{w}$ tekście odnotowałam $\mathrm{w}$ przypisach: fragment poświęcony Sokratesowi (przyp. 27), sformułowanie: „muzułmańskie przysłowie" (przyp. 34).

Przy opracowaniu starano się zachować indywidualne cechy stylu pisarskiego autora. Zostawiono pisownię tytułu i podtytułu powieści 
Wittlina: Sól Ziemi, Powieść o Cierpliwym Piechurze zamiast Sól ziemi, Powieść o cierpliwym piechurze, a także pisownię słowa essay.

Uwspółcześniono interpunkcję i ortografię. Ujednolicono pisownię małą i wielką literą. Stempowski nie był konsekwentny w zapisie sformułowań: Stara Austria, Chimera. Zmieniono zapis cyfrowy liczebnika w sformułowaniach: 17 laty na zapis słowny: siedemnastu laty, 2-go biura na: drugiego biura. Nie skorygowano zapisu: 93 uczonych.

Oznaczono kursywą tytuły dzieł przywołanych przez Stempowskiego w tekście, a także sformułowania w języku obcym.

W nawiasach kwadratowych odnotowano omyłki w maszynopisie.

M.Ch.

\section{Summary \\ Jerzy Stempowski on Józef Wittlin's Salt of the Earth [Sól Ziemi]}

In a 1936 text dedicated to Józef Wittlin's novel Jerzy Stempowski tries to position it within the context of the contemporary political, social and cultural events. He also analyses the artistic values of the novel in relation to the changes of the world-view caused by the traumatic events of the First World War. 